Annales Missiologici Posnanienses t. 20 (2015), s. 151-163

DOI: $10.14746 / \mathrm{amp} .2015 .20 .10$

KATARZYNA ANNA MICH

Uniwersytet Kardynała Stefana Wyszyńskiego / Cardinal Stefan Wyszyński University

\title{
Chrzest w Kościele nubijskim - próba rekonstrukcji liturgii w świetle analizy baptysteriów i wschodnich tradycji chrześcijańskich
}

Tajemnicza kraina wśród piasków pustyni w północno-wschodniej Afryce, nazywana od zarania wieków Nubią, rozciągała się w starożytności w południowej części doliny Nilu od pierwszej po szóstą kataraktę, między Elefantyną a Szendi. Przypuszcza się, że jej nazwa wywodzi się od staroegipskiego słowa nebu oznaczającego złoto. W przeszłości nosiła również nazwę Kusz, a jej mieszkańców utożsamiano z Kuszytami bądź Etiopczykami. Obszar ten zamieszkiwały ludy napływowe z basenu Morza Czerwonego - Blemmjowie, Noba, Egipcjanie, a także Żydzi, Grecy i Rzymianie. Kultura rodząca się na tym terenie ściśle związała się z Egiptem. Nubia narodziła się dzięki Egiptowi, ale także przez niego upadła. Omawiane tereny dzieli się na dwie części: Dolną Nubię i Górną Nubię.

Pierwszym chrześcijaninem tej ziemi według przekazów był, nawrócony przez apostoła Filipa, eunuch królowej Kandake. Choć św. Łukasz, autor Dziejów Apostolskich (Dz 8,26nn), nazywa ją królową Etiopii, zdaniem badaczy, Kandake (Welsby 31) było w rzeczywistości tytułem królowych z Meroe z Nubii. W apokryficznej Ewangelii Hebrajczyków szczegół mówiący o Królowej z Południa znany z Ewangelii Mateusza i Łukasza (Mt 12,42; Łk 11,31) zostaje uzupełniony o jej imię Meroe bądź Meruae (Starowieyski 112). Należy przypuszczać, że zastosowane pojęcie Etiopii odnosi się zarówno do dzisiejszej północnej części Etiopii, jak i do królestwa Meroe i w dużej mierze Nubii (Klinkowski 115-117). Nie wiadomo, czy za przykładem wspomnianego eunucha poszli inni, gdyż pierwsze wzmianki o istniejących tam wspólnotach chrześcijańskich pochodzą z drugiej połowy IV w.; wcześniej przyjmowano (do czasu badań w Qasr Ibrim), że ewangelizacja Nubii była rezultatem misji cesarskich Justyniana i Teodory z Bizancjum w połowie VI w. W latach sześć- 
dziesiątych IV w., gdy biskupem Aleksandrii był Atanazy, na wyspie File, na północy Nubii, powstało biskupstwo, do którego w czasach prześladowań Kościoła za panowania cesarza Dioklecjana uciekali niektórzy mnisi z Egiptu. Brak jest jednak jakichkolwiek źródeł o tym Kościele (Dijkstra 129-150). Zachowane świadectwa $\mathrm{z}$ koptyjskiego Egiptu potwierdzają, że na południu od granicy Egiptu z Nubią istniały chrześcijańskie wspólnoty (Ryl-Preibisz 293).

\section{Początki chrześcijaństwa w Nubii}

Wyniki badań archeologicznych prowadzonych na terenie Nubii, a zwłaszcza w Qasr Ibrim, wskazują, że tamtejsze chrześcijaństwo zostało ukształtowane znacznie wcześniej niż podczas cesarskich misji z VI w. Przemawia za tym inskrypcja, która została wyryta w świątyni w Kalabsza, poświęcona przywódcy Nobadów - Silko, zwycięzcy nad Blemmjami (Grillmeier, Hainthaler 268), a także list z Qasr Ibrim, odnaleziony podczas badań w 1976 r., napisany bardzo barbarzyńską greką. Datowanie na podstawie paleografii wskazuje, że list został sporządzony w połowie $\mathrm{V}$ w. Istotne są również trzy inne listy, pisane po koptyjsku, adresowane do Tantani, który sprawował władzę w Qasr Ibrim. Listy te napisane zostały przez chrześcijan i zawierają wiele zwrotów, które sugerują, że Tantani również był chrześcijaninem. W 1972 r. odkryto pozostałości świątyni wzniesionej przez faraona Taharkę w VII w. przed Chr., która następnie poprzez wbudowanie absydy w małej sali kolumnowej przekształcona została w chrześcijański kościół. Kościół ten jest prawdopodobnie jedną z najwcześniejszych budowli sakralnych w chrześcijańskiej Nubii, wzniesioną w drugiej połowie V w. (Plumley16-17).

\section{I.1. Powstanie królestw chrześcijańskich}

Na przełomie V i VI w. na terenie Nubii ukształtowały się trzy królestwa (Shinnie). Pomiędzy I i III kataraktą powstała Nobadia, ze stolicą w Faras, która od północy graniczyła z Makurią, rozwijającą się wokół Starej Dongoli. Najdalej na południu Nubii, nad Błękitnym Nilem, powstało królestwo Alodia ze stolicą w Soba.

\section{I.2. Chrystianizacja Nubii przez misje cesarskie}

Podstawowym źródłem na temat chrystianizacji Nubii (głównie królestw Nobadii i Alodii) przez misje cesarskie jest trzecia część Historii Kościoła na- 
pisanej około roku 580 przez monofizyckiego biskupa Efezu, Jana. Opisuje ona przebieg misji w Nobadii i Alodii. Biskup Jan był wysokim dostojnikiem na dworze Justyniana, a później patriarchą Konstantynopola. Jest to relacja jednostronna, lecz dotychczas jedyna, która omawia początek wiary chrześcijańskiej w Nubii (Świątek 139-152). W sposób barwny, aczkolwiek subiektywny przedstawia wydarzenia, które doprowadziły do przyjęcia w $543 \mathrm{r}$. przez Nobadię oraz prawdopodobnie w 580 r. przez Alodię chrześcijaństwa monofizyckiego (Frend 10-11).

Justynian pragnął utrzymać rządy w Egipcie i w Azji Mniejszej, ale także odzyskać dawne cesarstwo rzymskie. Aby osiągnąc ten cel, musiał być katolikiem na Zachodzie, ale na Wschodzie przeciwnikiem katolicyzmu. W politycznej grze podszytej religią Justynian wspierał wiarę katolicką, a jego żona Teodora monofizycką. On odgrywał swą rolę na Zachodzie, ona na Wschodzie (Koneczny 155). Na skutek działań dyplomatycznych cesarzowej udało się przez namiestnika Tebaidy opóźnić podróż na południe prochalcedońskiej misji cesarza, dzięki czemu misjonarze monofizyccy, pod przewodnictwem Juliana, przybyli na dwór nubijski jako pierwsi (Frend 11). Julian miał wsparcie w swoich działaniach od biskupa Tebaidy, Teodora (Hardy 90-91).

Około 543 r. władca Nobadii przyjął z rąk kapłana Juliana chrzest w obrządku monofizyckim. Zbiegło się to $\mathrm{w}$ czasie $\mathrm{z}$ zamknięciem przez cesarza Justyniana ostatniej egipskiej świątyni na wyspie File między 535 a 537 r. (Adams, Nubia Corridor to Africa 440-441). Teodozjusz, monofizycki patriarcha Aleksandrii, przed swoją śmiercią wyznaczył dla chrześcijan w Nubii biskupa Longinusa, którego konsekrował i któremu przekazał misję dokończenia dzieł rozpoczętych przez Juliana. Miał on wybudować pierwszy kościół w Nubii, ustanowić kapłanów i zorganizować liturgię.

Biskup Longinus w 580 r. ochrzcił króla, dostojników oraz mieszkańców najdalej wysuniętego królestwa nubijskiego, Alodii, która - podobnie jak Nobadia - przyjęła wyznanie monofizyckie.

Jan z Biclar, późniejszy biskup Gerony, był świadkiem przybycia do Konstantynopola posłów z Makurii, którzy przywożąc dla cesarza dary, zwrócili się z prośbą do niego o przyjaźń. Wyrazili również pragnienie przyjęcia przez Makurię wiary chrześcijańskiej (Adams, Nubia Corridor to Africa 442-444). Królestwo przyjęło chrzest w wyznaniu duofizyckim, ortodoksyjnym w 569 r., z rąk misjonarzy chalcedońskich, którzy zostali wysłani przez cesarza Justyna II. Kronika Jana z Biclar sugeruje sojusz, o charakterze politycznym „Wysłannicy plemienia Makkurytów przybyli do Konstantynopola, złożywszy dary: kły słoni i żyrafę, uzyskali dla siebie pokój z Rzymem". Relacja była spisana w siódmym roku panowania cesarza Justyna Młodszego, czyli po czterech latach od oficjalnego chrztu Makurii. W kronice Izydora Sewilli data chrztu Makurii przypada na 567 r., a według biskupa Jana z Biclar Makuria przyjęła 
chrzest w trzecim roku panowania Justyna Młodszego, czyli w roku 568 lub 569 (Jan z Biclar 114).

\section{I.3. Charakter chrześcijaństwa w Nubii}

Dworski ceremoniał chrześcijańskiej Nubii i tytuły najwyższych urzędników wywodziły się z tradycji Bizancjum. Co prawda władca mógł nawet sprawować liturgię, jednak władza świecka pozostawała w zasadzie oddzielona od nubijskiego Kościoła, nominalnie podlegającego koptyjskiemu patriarsze Aleksandrii, który osobiście mianował wszystkich biskupów nubijskich (Lemiesz 2005).

Językiem liturgicznym Kościoła w Nubii był grecki, czego świadectwem są zachowane fragmenty ksiąg liturgicznych, inskrypcje grobowe i napisy towarzyszące malowidłom (Plumley 23). W kościołach posługiwano się również językiem koptyjskim oraz miejscowym, staronubijskim, czego dowodzą zachowane inskrypcje i fragmenty ksiąg liturgicznych (Welsby 447-448). Bardzo ważnym odkryciem w Qasr Ibrim było znalezienie kilku fragmentów Ewangelii według św. Marka pisanej po grecku, ładną uncjałą z V w. Jest ona wiązana z okresem działań misji Justyniana i Teodory. Pergamin najprawdopodobniej został przywieziony z Bizancjum w okresie misji cesarskich (Plumley 18).

Chrześcijaństwo wprowadza ujednolicenie formy pochówku. Już w pierwszych latach po chrystianizacji zauważa się zanik cmentarzysk kurhanowych (groby elitarne, które były charakterystyczne dla okresu postmeroickiego) na rzecz grobów chrześcijańskich, choć często stosowane były obie formy. Groby sytuowane były na osi o kierunku wschód-zachód. Zmarłych składano w pozycji wyprostowanej, z głową układaną wyłącznie w kierunku zachodnim, rękoma wzdłuż ciała, co było silnie związane z chrześcijańską eschatologią. Z czasem pojawiły się jednak pewne różnice. Obok najprostszych grobów typu box-grave, zaczęto wznosić różnej wielkości mastaby z cegieł wypalanych i obłożonych białym, wapiennym tynkiem. Pojawiały się pochówki w kościołach oraz klasztorach. Niedaleko Starej Dongoli odkryto dwie komory grobowe wykute w skale z miejscami na pochówek. Nad wejściem do jednej z nich wyryty był znak krzyża. Nie znaleziono jednak żadnych szczątków ludzkich wewnątrz (Drzewiecki 12).

Pod koniec VI w. trzy królestwa nubijskie były chrześcijańskie, a przynajmniej ich przywódcy oficjalnie wyznawali nową wiarę. Nobodia i Alodia związały się z chrześcijaństwem monofizyckim. Natomiast Makuria przyjęła chrzest w wyznaniu duofizyckim w 569 r., z rąk misjonarzy chalcedońskich, którzy zostali wysłani przez cesarza Justyna II, następcę Justyniana. Królestwa nubijskie ewangelizowała nie Aleksandria, ale Konstantynopol, nawet 
jeśli ewangelizatorami byli Aleksandryjczycy na wygnaniu (Arnauld 97). Jak twierdzi Dominic Arnauld (91):

Historia ewangelizacji królestw nubijskich toczyła się na tle teologicznych sporów i napięć pomiędzy Konstantynopolem, Aleksandrią i Antiochią, które rozdzierały tkankę Kościołów Wschodu. Podziały między Kościołami dotknęły nubijskie wspólnoty chrześcijańskie.

\section{Dzieje chrześcijańskiej Makurii}

W VII w. Arabowie dwukrotnie podjęli nieudane próby inwazji na Nubię. W 651 r. wojska arabskie pod wodzą Abdalli ibn Abi Sarha podeszły pod samą Dongolę, jednak Nubia była zbyt trudna do utrzymania. Zawarty w $652 \mathrm{r}$. z królem Qalidrutem traktat pokojowy - baqt - gwarantował Nubijczykom niezależność i wolność w zamian za coroczny trybut jeńców i obietnicę wybudowania w Dongoli meczetu. Przez następne wieki Makuria utrzymywała stałe kontakty dyplomatyczne ze światem arabskim. Pakt o nieagresji był zarazem pewnego rodzaju traktatem handlowym, który nakładał na Nubijczyków roczny trybut w niewolnikach (Jakobielski 2013: 5). Przez ponad 600 lat umowa ta stanowiła podstawę stosunków między Nubią a arabskim Egiptem. Na czas od końca VII do XII w. przypadł największy rozkwit państwa, jednakże królestwo Makurii pozostawało odcięte od innych krajów chrześcijańskich z powodu najazdów Arabów i opanowania przez nich Egiptu. Historyczne potwierdzenie unii między Makurią a Nobadią mamy z 704 r., kiedy Merkurios dokonał zjednoczenia obu królestw, być może pod wpływem zagrożenia ze strony muzułmańskiej. Wydaje się, że wczesne spory między dwoma rywalizującymi Kościołami ustały. Merkurios podporządkował zjednoczony Kościół władzy koptyjskiego patriarchy Aleksandrii.

Najprawdopodobniej ortodoksyjny Kościół melchicki przetrwał w Nubii, a nawet - jak świadczą dane ikonograficzne, w pierwszej połowie XI w., za czasów episkopatów Jooannesa III, Marianosa i Merkuriosa - dominował w Faras. Za takim stanem rzeczy przemawiają również argumenty historyczne faworyzowania melchitów w Egipcie za czasów zarządcy Al.-Hakima (Jakobielski, „Chrześcijaństwo...” 390).

Około 750 r. król Kyriakos interweniował w obronie patriarchy Aleksandrii, który został uwięziony przez zarządcę Egiptu. Według źródeł Kyriakos wraz z armią podszedł pod Fustat (Kair).

W X w. Makuria zawarła unię personalną z Alodią (Ochała 183). Brak jednak zachowanych źródeł potwierdzających ten fakt. Wiadomo, że w tym okresie oba królestwa łączyły więzy krwi, m.in. Mas' udi podaje imię Kubri 
ibn Surur jako władcę obu państw w 943 r. Zjednoczenie Makurii z Alodią potwierdza oficjalna tytulatura królewska zaświadczona $\mathrm{w}$ drugiej połowie XII w. (Jakobielski, „Chrześcijaństwo w Nubii” 7).

Na początku IX w. Kalifat drogą dyplomatyczną zażądał od króla Zacharii I wywiązania się z postanowień traktatu, ponieważ Nubia ich nie respektowała. Król wysłał swojego syna Georgiosa z poselstwem do Bagdadu, aby podjął rozmowy z kalifem i ocenił siłę wojskową armii Abbasydów. Poselstwo osiągnęło sukces, anulowano bowiem zaległości i ustalono płatności co 3 lata w miejsce opłat dorocznych.

Nubia rozkwitła na przełomie IX i X w., co manifestowało się rozbudową miast, wznoszeniem wspaniałych kościołów i fundowaniem klasztorów, co czyniono z bizantyjskim przepychem. Dwór królewski wzorowany był na dworze Bizancjum. Jednak tron przechodził nie na syna władcy, lecz na syna siostry królewskiej. Choć król nie był zwierzchnikiem Kościoła, to niejednokrotnie pośredniczył w sprawach kościelnych. Kilku z nich miało święcenia kapłańskie. Transmisja władzy królewskiej do małych ośrodków aglomeracyjnych odbywała się przez lokalny kler.

Od XIII w. Makurią wstrząsały walki o tron królewski, co doprowadziło pomiędzy XIV a XVI w. do całkowitego upadku chrześcijańskich królestw nubijskich, kiedy to Arabowie opanowali te terytoria. Chrześcijańska cywilizacja Makurii narodziła się dzięki Egiptowi i upadła pod wpływem tego państwa. Kościół w Nubii nie przetrwał, gdyż opierał się na poparciu króla, jemu też podlegał i był uwarunkowany sytuacją królestwa. Gdy Makuria upadła, chrześcijaństwo, które było nieugruntowane dostatecznie w społeczeństwie nubijskim, upadło również (Pietras).

\section{II.1. Architektura sakralna Makurii w okresie chrześcijańskim}

Chrześcijańska monumentalna architektura sakralna pojawiła się w Makurii w wyniku scentralizowania chrześcijaństwa, co dokonało się w rejonie dongolańskim wraz z przybyciem misjonarzy melchickich z Bizancjum. Zauważa się, że w tym czasie nastąpił znaczący rozwój budownictwa sakralnego, pojawiły się założenia architektoniczne, w których najważniejszą rolę odgrywała świątynia chrześcijańska (Gartkiewicz 43-133).

Prawdopodobnie przed oficjalnym chrztem Makurii z rąk misjonarzy z Bizancjum lokalne grupy chrześcijan, które były obecne na tym terenie, używały do udzielania chrztu naturalnych zbiorników wodnych, jak rzeka Nil. Gdy chrześcijaństwo stało się oficjalną religią państwową, nastąpiła chrystianizacja całego królestwa. W kościołach powstawały baptysteria, w których począt- 
kowo biskup, a następnie prezbiter udzielał chrztu w wyznaniu melchickim (Adams, „Architectural...” 87-90).

Architektury chrześcijańskiej nie można zrozumieć bez jej liturgicznego kontekstu. Liturgia bowiem usprawiedliwiała jej egzystencję. Dzięki źródłom archeologicznym i historycznym jest możliwe odtworzenie wyglądu wnętrz kościołów, ale także próba rekonstrukcji obrzędów liturgicznych, które się w nich odbywały, bowiem wielowiekowa ewolucja architektury sakralnej pozwala na prześledzenie kolejnych etapów rozwojowych i zmian w wyposażeniu liturgicznym, a konfrontacja zabytków nubijskich z zabytkami z innych terenów chrześcijańskiego Bliskiego Wschodu pozwala na ustalenie, czy znane z Nubii rozwiązania dotyczące liturgicznego wykorzystywania kościołów były autochtoniczne czy też zapożyczone z zewnątrz.

\section{Badania nad liturgią Kościoła nubijskiego}

Podstawową trudnością w badaniach nad liturgią nubijską jest nieprecyzyjne datowanie wielu kościołów, a także słaby stan zachowania źródeł pisanych. $\mathrm{Na}$ Nubię w ciągu wieków oddziaływały zarówno Bizancjum, jak i Egipt koptyjski, należy więc przypuszczać, że te ośrodki miały wpływ na liturgię nubijską. Trzeba jednak stwierdzić, że liturgia bizantyjska mogła bezpośrednio oddziaływać na Nubię tylko do zajęcia przez Arabów Egiptu. W okresie przed ikonoklazmem liturgię bizantyjską można identyfikować tylko z liturgią Konstantynopola.

Misjonarze, chrystianizujący Nubię z upoważnienia cesarstwa, Julianos i Longinos przebywali przez pewien czas w Konstantynopolu. Doktor Gołgowski uważa, ,że mogli oni przynieść do Nubii pewne zwyczaje liturgiczne praktykowane w stolicy cesarstwa" (46), jednak obaj opowiadali się za aleksandryjską tradycją liturgiczną, antychalcedońską, a nie za bizantyjską. Jednakże obrzędy chrzcielne monofizyckie i duofizyckie najprawdopodobniej nie różniły się pomiędzy sobą.

\section{III.1. Sakrament chrztu w Nubii}

Chrzest jest podstawowym sakramentem w religii chrześcijańskiej, udzielany jest przez zanurzenie lub polanie głowy wodą w imię Trójcy Świętej. Ustanowiony został przez zmartwychwstałego Chrystusa, który nakazał udzielać go wszystkim narodom na całym świecie. Przesłanie ewangeliczne podkreśla konieczność tego sakramentu do zbawienia. Chrzest jest dla wier- 
nego włączeniem w śmierć i zmartwychwstanie Chrystusa przez symboliczne zanurzenie się w wodzie i powstanie. Nowo ochrzczony staje się członkiem Kościoła. Od samego początku chrześcijaństwa żadna grupa odłączona od Kościoła ortodoksyjnego nie odrzucała tego sakramentu. Trudności dotyczyły sposobu udzielania chrztu, a także sposobu pojmowania jego skuteczności.

Znane teksty liturgiczne z Nubii, które w małym stopniu pomagają w badaniach nad liturgią chrzcielną, znajdują się na ścianie kościoła w Kasr el Wizz (Brans 206-211), a także w Dolnym Kościele w Banganarti (Łajtar 226).

Znajdujący się w Kasr el Wizz tekst kantyku Błogosławcie Pana, wszystkie dzieła Pańskie, zaczerpnięty z Księgi Daniela (Dn 3,57-81), był śpiewany tydzień przed Wielkanocą, według niektórych badaczy, związany był z chrztem w Syrii oraz w Egipcie w czasach wczesnochrześcijańskich. Umieszczenie tekstu na wewnętrznych ściankach basenu chrzcielnego potwierdza jego związek z omawianym sakramentem.

Natomiast tekst greckiej modlitwy na ołtarzyku wmurowanym w posadzkę Rafaelionu w Banganarti:

I. Ty powiedziałeś te słowa swoim apostołom: Jeśli ktoś nie narodzi się ponownie, nie uda się mu wejść do królestwa Bożego. Jeśli nie zmieni się i nie będzie jak dzieci, nie wejdziecie do Królestwa Bożego [...] Zachowaj nas przez swojego Jednorodzonego Syna [...].

II. [...] Zbawicielu, Ty [...] [masz] cenione [...] ze stołu, Ty, Boże, który karmisz pięcioma chlebami pięć tysięcy mężczyzn nie licząc kobiet i dzieci, i nie było nadmiaru, teraz karm nas pokarmem Twoim, pokarmem, który jest w niebie, przez Jego [powinno Twoich] uczniów, błogosławiony jesteś Panie.

III. $[\ldots]$ z natury $[\ldots]$ błagamy Cię $[\ldots]$ aby Duch Swięty przyszedł $[\ldots]$ wedle mocy $[\ldots]$ te mleko, zmień $[\ldots]$ i przemień to tak, że $[\ldots]$, o Panie, $[\ldots]$ że $[\ldots]$ na odpuszczenie grzechów.

Sugeruje, że bardzo prawdopodobne jest, iż powyższe modlitwy są ze sobą ściśle powiązane i razem tworzą ramy liturgii. Kolejność modlitwy jest najwyraźniej I-II-III. W modlitwach I i II (anamnesis) autor korzysta $\mathrm{z}$ wypowiedzi Jezusa, jakie podano w J 3,3 i Mt 18,3, jak również do perykopy o cudownym rozmnożeniu chleba zawartej w Mt 14,20-21. Modlitwa III (epikleza) jest zwrotem do Ducha Świętego, aby przyszedł i przemienił ofiary na ołtarzu, mleko. Mleko odgrywa istotną rolę w jednej tylko znanej liturgii, mianowicie liturgii chrzcielnej. Podawanie mleka i miodu nowo ochrzczonym jest dobrze potwierdzone w Kościele Łacińskim. Na Wschodzie, najwyraźniej ogranicza się do Patriarchatu Aleksandryjskiego. Jest ono wymienione w Tradycji apostolskiej Pseudo-Hipolita, w tekście, który prawdopodobnie powstał w V w. i opisuje liturgiczne praktyki Patriarchatu Aleksandrii. Napis na ołta- 
rzu z Banganarti musi również odnosić się do liturgii chrztu. Świadczy o tym, że zwyczaj podawania mleka (i miodu) wśród nowo ochrzczonych również istniał w Kościele nubijskim, co potwierdza jego przynależność do Patriarchatu Aleksandryjskiego (Żurawski, „Madonna...” 28-31).

W tych okolicznościach jedynym bezpiecznym źródłem są informacje dostarczane przez wykopaliska, jednakże przy próbie rekonstrukcji liturgii należy informacje uzyskane z wykopalisk porównać ze źródłami patrystycznymi z innych obszarów chrześcijańskich. Nie można zapominać, że liturgia nie tylko miała odzwierciedlenie w materiale archeologicznym, ale także w nauczaniu ojców Kościoła i innych teologów okresu patrystycznego (Mokrzycki).

Obecny stan wiedzy na temat liturgii w Nubii nie pozwala na całkowite zrekonstruowanie obrzędów chrzcielnych. Nie zostały dotąd odnalezione żadne teksty mówiące bezpośrednio o liturgii.

\section{III.2. Przemiany obrządku chrzcielnego na przykladzie Selib}

Na przykładzie znalezionych basenów chrzcielnych w Selib zauważalne jest, że w okresie od VI do XII w. następowała ewolucja liturgii chrzcielnej. Można wyodrębnić trzy fazy przemian obrządku chrzcielnego.

Początkowo chrzest był udzielany przez zanurzenie (łac. immersio) w basenie chrzcielnym. W fazie środkowej wydaje się, że zanurzenie zostało zastąpione przez polanie wodą (łac. affusio); nie ulega wątpliwości, że był udzielany również $\mathrm{w}$ basenie chrzcielnym. W ostatniej fazie basen chrzcielny został zastąpiony przez murowane wygrodzenie na posadzce kościoła, gdzie chrztu udzielano poprzez aspersję bądź też pokropienie (łac. aspersio). Biorąc pod uwagę, że ostatnie baptysterium datowane jest na XII w., można przypuszczać, że w tym okresie dorośli mieszkańcy rejonu dongolańskiego byli już ochrzczeni i chrztu udzielano jedynie dzieciom.

\section{III.3. Próba rekonstrukcji modelu liturgicznego}

W liturgii chrzcielnej można wyznaczyć poszczególne etapy chrzcielnego wtajemniczenia. Liturgia jerozolimska z IV w. jest liturgią całego Kościoła, gdyż w odniesieniu do chrztu różnice dotyczą jedynie szczegółów. Całą liturgię chrzcielną można podzielić na dwie części: obrzędy przedchrzcielne i główne. Do tych pierwszych należą wyrzeczenie się Szatana, wyznanie wiary, zdjęcie starych szat oraz przedchrzcielne namaszczenie (Danielou 9).

Nie jest wykluczone, że przed chrztem w Nubii odbywała się ablucja stóp. Wskazuje na to mały kwadratowy basen niemal poniżej poziomu chodnika 
w kościele z Granitowymi Kolumnami. Brak takich małych basenów w innych baptysteriach z mniejszą powierzchnią może wskazywać, że ablucji dokonywano przed wejściem do baptysteriów (Godlewski 1979, 54). W świadectwach o tym obrzędzie czytamy, że po ceremonii nowo ochrzczony przed założeniem obuwia umywał sobie jeszcze stopy, jak u św. Ambrożego w De sacramentis: „Wyszedłeś z sadzawki chrzcielnej [...] biskup [...] mając podwiązane szaty, umył ci nogi” (Eckmann 112). Nie ma żadnej wzmianki o tej ceremonii na Wschodzie. Świadectwo pątniczki Egerii z V w. nie informuje o umywaniu nóg przy chrzcie (Wiśniewski 75-93).

Istnieją dwa istotne momenty przed wejściem do baptysterium: wyrzeczenie się Szatana i wyznanie wiary. Ojcowie Kościoła nauczają, że wypowiadając formułę wyrzeczenia się Szatana, kandydat powinien zwrócić się ku Zachodowi, wyznając wiarę, skierowywać się ku Wschodowi (Danielou 12-23). Baptysteria w Nubii w zdecydowanej większości ukierunkowane są na osi zachód-wschód, co wskazuje, że ówczesna symbolika Wschodu była obecna i praktykowana.

Neofita wchodził do baptysterium najczęściej w nawie wschodniej, w kościołach o planie centralnym w południowym końcu transeptu. Baseny chrzcielne umieszczone były w centrum baptysterium. Baptysteria były pomieszczeniami zamkniętymi, całe zgromadzenie liturgiczne nie było obecne podczas ceremonii - było to związane z wymogami przyzwoitości, gdyż chrzczeni ludzie schodzili do basenu chrzcielnego zupełnie nadzy. Tylko w Dongoli w dwóch kościołach obok baptysterium było pomieszczenie, które mogłoby być szatnią. Niemniej jednak prawdopodobne jest, że neofici byli rozbierani w baptysterium, ponieważ mało prawdopodobne wydaje się, że rozbierali się w nawie kościoła (Godlewski 54).

Prawdopodobnie następowało namaszczenie przedchrzcielne, które pojawia się w liturgii jerozolimskiej, której elementy były wówczas powszechne $\mathrm{w}$ wielu innych ośrodkach chrześcijańskiego Wschodu. Jedna z interpretacji znalezionego naczynia w Starej Dongoli w kościele z Granitowymi Kolumnami sugeruje, że to naczynie było podstawą do naczynia ze świętym olejem. Nie można określić, czy woda używana podczas ceremonii chrztu była konsekrowana, jednakże w tradycji chrześcijańskiego Wschodu od IV w. chrzest był poprzedzany poświęceniem wody (Danielou 28).

W przeciwieństwie do całej tradycji chrześcijańskiej ówczesnego świata chrzest w Nubii, z wyjątkiem najwcześniejszego okresu chrystianizacji królestwa, był prawdopodobnie udzielany przez potrójne polanie bądź też pokropienie głowy katechumena. Nawet w basenach, które są bardzo duże i głębokie, nie ma śladu, by w przeszłości były wypełniane wodą. Baseny te bowiem pozbawione są kanalizacji. Ściany basenów w Dongoli pokryte są malowidłami, na których nie ma śladów mineralnych, co wyklucza napełnianie piscyny 
wodą (Godlewski 55). Jednakże Bogdan Żurawski uważa, że w najstarszym basenie chrzcielnym w kościele w Selib chrzest mógł się odbywać poprzez zanurzenie (Żurawski, „Karawana...” 35-37).

Po namaszczeniu nowo ochrzczonym nakładano białe szaty, które symbolizowały nowego człowieka, a także Chrystusa. Wyobrażały również uczestnictwo w chwale zmartwychwstałego Chrystusa (Danielou 34). Ten element trudny jest do uchwycenia archeologicznego, z punktu widzenia liturgii musiał on być obecny w ceremonii chrzcielnej.

Modlitwa z kościoła w Banganarti wskazuje, że po chrzcie neofitom dawano do spożycia mleko i miód. Sakramentu bierzmowania zazwyczaj udzielano w baptysterium, jednakże w większych kościołach w specjalnym miejscu zwanym consignatorium (Żurawski, „Madonna...” 28-31), poprzez namaszczenie krzyżmem.

Po bierzmowaniu nowo ochrzczeni formowali orszak, aby przejść w uroczystej procesji z baptysterium do kościoła (Danielou 35). W Nubii procesja wychodziła z baptysterium, przechodziła prawdopodobnie korytarzem za absydą, by przez północne prothesis wejść do kościoła na uroczystą liturgię, w której uczestniczyli wszyscy wierni (Godlewski 55).

\section{Zakończenie}

W programie ikonograficznym nubijskich baptysteriów pojawiają się trzy schematy przedstawień: św. Jana Chrzciciela, św. Stephanosa (Szczepana) i Chrystusa Emmanuela.

Podobnie jak większość aspektów chrzcielnej architektury, kształt basenu ma niewątpliwie znaczącą wartość symboliczną (Ferguson 819-821). Baseny $\mathrm{w}$ formie krzyża mają oczywiste teologiczne znaczenie: katechumen dokonuje fizycznego zanurzenia w krzyżu, który prowadzi go do duchowego odrodzenia (Kostof 50). W formie basenu z dwoma zejściami rytuał chrztu fizycznie naśladował odrodzenie, gdyż katechumen wchodził do grobu, którym było źródło chrzcielne, aby wyjść odrodzony i wolny od grzechu, co wiąże się z chrześcijańską narracją męki Pańskiej, której centrum jest grób i zmartwychwstanie (Caraher). Katechumen wchodził nagi do źródła wody. Nagość symbolizuje grzeszność, która wymaga odkupienia i zbawienia. Nagość u Adama i Ewy stała się znakiem przekleństwa. Upadły człowiek potrzebował nowej szaty, aby mógł żyć w jedności i harmonii z Bogiem. Poprzez chrzest w imię Chrystusa ludzkość pozbyła się swojej na g o ś c i jako symbolu przekleństwa. Biała szata założona po chrzcie jest symbolem przy oblec zenia się w Jezusa Chrystusa. 


\title{
BAPTISM IN THE NUBIAN CHURCH - AN ATTEMPT TO RECONSTRUCT THE LITURGY IN THE LIGHT OF THE ANALYSIS BAPTISTERIES AND EASTERN CHRISTIAN TRADITIONS
}

\begin{abstract}
AB STR ACT
Although archaeological evidence shows that Christianity existed in Nubia before the official mission of evangelization of Byzantium, however, it did not then have a centralized form. The imperial missions of Justinian and Theodora established the new faith, and in effect the Nubian Christianity began to erect monumental temples dedicated to the new God. On the basis of Nubian baptisteries, as well as contemporary baptismal liturgy in the East, the author attempts to reconstruct the baptismal liturgy in Nubia, primarily in the area of the kingdom of Makuria.
\end{abstract}

Keywords: Baptism, liturgy, Nubia, Kingdom of Makuria, baptisteries, Selib, Banganarti, Old Dongola

Słowa kluczowe: chrzest, liturgia, Nubia, Makuria, baptysteria, Selib, Banganarti, Stara Dongola

\section{BIBLIOGRAFIA}

Adams, William Yewdale. „Architectural Evolution of the Nubian Church, 500-1400 A.D.” Journal of the American Research Center in Egypt (1965) 4: 87-90.

Adams, William Yewdale. Nubia Corridor to Africa, New Yersey: Princeton University Press, 1977.

Arnauld, Dominic. „Chrystianizacja Starożytnej Nubii.” Tłum. L. Nieścior. Konflikty perspektyw w historii i praktyce misji. Red. P. Zając. Poznań: Uniwersytet im. Adama Mickiewicza Wydział Teologiczny, 2009. 81-102.

Barns, John. „A text of the Benedictite in Greek and Old Nubian from Kasr el Wizz”. Journal Egyptian Archaeology 60 (1974): 206-211.

Caraher, Wiliam. „Early Christian Baptisteries: A Short Discussion.” Dostęp 28.09.2015. <http:// www.scribd.com/doc/29902863/Early-Christian-Baptisteries-Working>

Danielou, Jean. „Symbolika obrzędów chrzcielnych.” Pisma Wybrane. Kraków: Wydawnictwo WAM, 2011: 9-39.

Dijkstra, Jitse Harm Fokke. Religious Encounters on the Southern Egyptian Frontier in Late Antiquity (298-642). Groningen: University Library Groningen, 2005.

Drzewiecki, Mariusz. Ufortyfikowane założenia architektoniczne w kontekście osadniczym w Górnej Nubii w czasach królestwa Makurii. [nieopublikowana dysertacja doktorska], Poznań, 2012.

Eckmann, Augustyn. „Liturgia i teologia chrztu św. Augustyna w Mediolanie”, Vox Patrum 8 (1988): 101-118.

Ferguson, Everett. Baptism in the Early Church. History, Theology, and Liturgy in the First Five Centuries. Grand Rapids. Cambridge: Wm. B. Eerdmans Publishing, 2009.

Frend, W.H.C. "The Mission to Nubia: An Episode in the struggle for Power in Sixth Century Byzantium." Etudes et Travaux 8 (1973): 9-17. 
Gartkiewicz, Przemysław. "An indroduction to the history of Nubian church Architecture." Nubia Christiana 1 (1982): 43-133.

Godlewski, Włodzimierz. Les baptistères nubiennes. Varsovie: Éditions Scientifiques de Pologne, 1979.

Gołgowski, Tadeusz. „Liturgia nubijska i problem jej rekonstrukcji.” Saeculum Christianum 14 (2007): 43-51.

Grillmeier, Aloys., Hainthaler Theresia. Christ in Christian tradition From the Council of Chalcedon (451) to Gregory the Great (590-604): The Church of Alexandria with Nubia and Ethiopia after 451. London: Westminster John Knox, 1996.

Hardy, E. R. „The Patriarchate of Alexandria: A Study in National Christianity.” Church History 15 (1946): 81-100.

Jakobielski, Stefan. „Chrześcijaństwo nubijskie w świetle najnowszych badań”. Azis S. Atiya. Historia kościołów wschodnich. Tłum. S. Jakobielski i in. Warszawa 1978. 385-393.

Jakobielski, Stefan. „Chrześcijaństwo w Nubii.” Wielkie Królestwa Chrześcijańskie w Nubii. Red. Dobiesława Bagińska, Poznań: Muzeum Archeologiczne, 2013: 5-14.

Jan z Biclar. „Kronika Jana z Biclar”. Tłum. S. Grabowski, Warszawskie Studia Teologiczne 8 (1995): 107-125.

Klinkowski, Jan. „Obraz krainy Kusz (Etiopii) i jej mieszkańców w tradycji biblijnej i świadectwach pozabiblijnych.” Perspetiva Legnickie Studia Teologiczno-Historyczne 7.1 (2008): 104-125.

Koneczny, Feliks. Cywilizacja bizantyjska. Tom. 1. Komorów: Antyk - Marcin Dybowski, 1996.

Kostof, Spiro. The Orthodox Baptistery of Ravenna. New Haven: Yale University Press, 1965.

Łajtar, Adam. „Inscibed altar top (?).” Sudan Ancient Treasures. An Exhibition of Recent Discoveries fromthe Sudan National Museum. Red. Derek A. Welsby, Julie A. Anderson, London: The British Museum Press, 2004: 226.

Lemiesz, Marek. „Archeologia Sudanu - Okres chrześcijański.” Dostęp 28.09.2015. <http://www. muzarp.poznan.pl/muzeum_new/muz_pol/wystawy_stale/sudan/chrzesc.html>

Mokrzycki, Bronisław. Droga chrześcijańskiego wtajemniczenia. Warszawa: Akademia Teologii Katolickiej, 1983.

Ochała, Grzegorz. „Kalendarz liturgiczny Kościoła nubijskiego w świetle zachowanych fragmentów nubijskich lekcjonarzy." U schyłku starożytności -Studia źródłoznawcze 12 (2013): 183-232.

Pietras, Henryk. „Zasypany Kościół.” Dostęp 28.09.2015. <http://mateusz.pl/wam/poslaniec/0504kosciol.htm>

Plumley, J.M. „New evidence on Christian Nubia in the Light of Recent Excavations.” Nubia Christiana 1 (1982): 15-24.

Ryl-Preibisz, Ida. „File. Starożytne miejsce kultu i ośrodek wczesnego chrześcijaństwa.” Sympozja kazimierskie poświęcone kulturze świata późnego antyku i wczesnego chrześcijaństwa - Miejsca święte w epoce późnego antyku. Red. B. Wronikowska i D. Próchniak. tom 5. Lublin: Katolicki Uniwersytet Lubelski, 2005. 291-300.

Shinnie, Peter L. Medieval Nubia and Byzantium. Khartum: Sudan Antiquities Service, 1954.

Starowieyski, Marek. Apokryfy Nowego Testamentu. Tom 1. Kraków: WAM, 2003.

Świątek, Adam. „Chrystianizacja Nubii w VI wieku w świetle «Historii Kościoła» Jana z Efezu.” Nowy Filomata 10 (2006):139-152.

Welsby, Derek A. The Medieval Kingdoms of Nubia. Pagans, Christians and Muslims along the Middle Nile. London: British Museum Press, 2002.

Wiśniewski, Piotr. „Dzieje wielkoczwartkowego obrzędu „Mandatum”. Liturgia Sacra 10 (2004): 75-93. Żurawski, Bogdan, „Karawana do Selib.” Academia. Magazyn PAN 7.2 (2011): 35-37.

Żurawski, Bogdan. „Madonna z Banganarti.” Academia. Magazyn PAN 3.1 (2007): 28-31.

Katarzyna Anna Mich, absolwentka archeologii i teologii na Uniwersytecie im. Adama Mickiewicza w Poznaniu. Doktorantka misjologii na Uniwersytecie Kardynała Stefana Wyszyńskiego w Warszawie. 


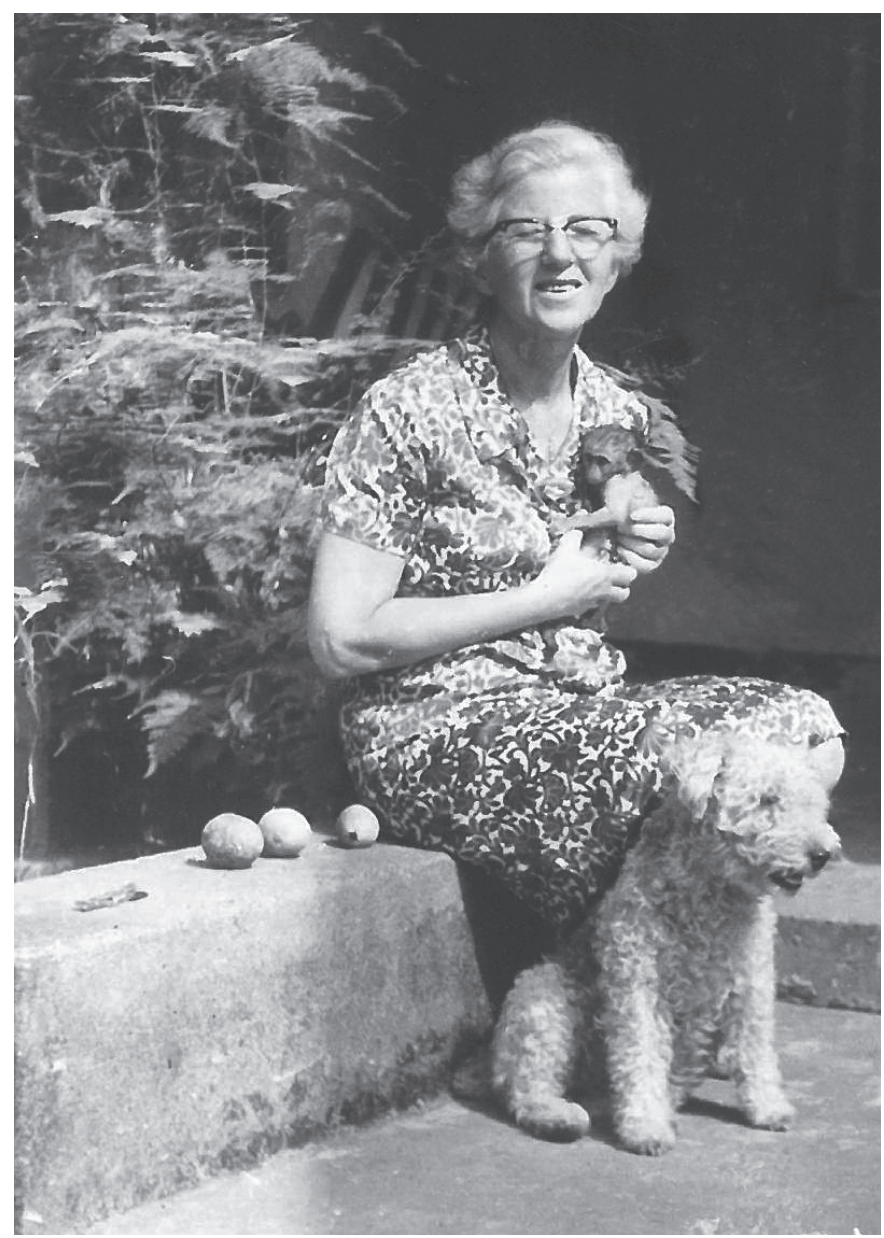

